\title{
Post-COVID Chronic Fatigue Syndrome: New Challenge Ahead
}

\author{
Adwitiya Ray ${ }^{1}$, Neharika Saini ${ }^{2}$, Ravi Parkash ${ }^{3}$, Naresh Kumar ${ }^{4}$, \\ Harsh Kumar ${ }^{5}$ \\ ${ }^{1}$ Junior Resident, ${ }^{3}$ Senior Resident, Dept. of Psychiatry, ${ }^{2}$ Senior Resident, Dept. of Medicine, \\ ${ }^{4}$ Junior Resident, Dept. of Forensic Medicine, Pt. B.D. Sharma PGIMS Rohtak \\ ${ }^{5}$ Medical Graduate (MBBS) AIIMS Rishikesh \\ Corresponding Author: Ravi Parkash
}

\begin{abstract}
Coronavirus disease 2019 (COVID-19) is a viral infection that causes various respiratory, gastrointestinal, and vascular symptoms. The acute illness phase lasts for about 2-3 weeks. However, there is increasing evidence that a percentage of COVID-19 patients continue to experience long-lasting symptoms characterized by fatigue, dyspnea, myalgia, exercise intolerance, and sleep disturbances, difficulty concentrating, anxiety, fever, headache, malaise, and vertigo. Similar symptoms are reported by patients who having myalgic encephalomyelitis/ chronic fatigue syndrome (ME/CFS). ME/CFS pathology is not known: it is thought to be multifactorial, resulting from the dysregulation of multiple systems in response to a particular trigger. There is a resemblance between postacute COVID-19 symptoms and ME/CFS. However, at present, there is inadequate evidence to establish COVID-19 as an infectious trigger for ME/CFS. Further research is required to determine the natural history of this condition, as well as to define risk factors, prevalence, and possible interventional strategies.
\end{abstract}

Keywords: chronic fatigue syndrome, COVID19 , human coronavirus, myalgic encephalomyelitis, post-infectious fatigue, review

\section{INTRODUCTION}

In 2019, December the first case of novel coronavirus (COVID-19) was detected in China, and in January 2020, the
World Health Organization announced its upsurge, an international public health emergency.[1] To date, more than 80 million people have been infected with the severe acute respiratory syndrome coronavirus-2 (SARS-CoV-2) worldwide and at least 1.7 million have expired. [2]

In the initial phase of this pandemic, people and doctors' attention was focused on the acute morbidity and mortality associated with COVID-19. However, there have already been several reports regarding persistent and prolonged physical and neuropsychiatric symptom continuation following SARS-CoV-2 infection. Followup studies reveal that patients with mild and even asymptomatic infection may experience cognitive disablement, delirium, severe weariness, and mood symptoms. $[3,4]$

The term Long COVID is defined as the presence of signs and symptoms that develop during or following an infection consistent with COVID-19 and continue for 4 weeks or longer. The term includes "postacute COVID-19" (4-12 weeks) and "postCOVID syndrome" (12 weeks or longer). [5] In this article, we aim to review symptoms, possible mechanisms, and management strategies of long COVID.

\section{History of similar Sequel}

The effect on the brain, following viral infections, has also been seen during previous pandemics in the ninetieth and 
twentieth centuries. Table 1 shows the various symptoms that had developed after the different viral infections and the terms that had been used at that time.

\begin{tabular}{|c|c|c|c|c|}
\hline Study & Year & Infection & Term & symptoms \\
\hline $\begin{array}{l}\text { Honigsbaum M } \\
\text { et al,2020 [7] }\end{array}$ & 1889 & Russian flu & & $\begin{array}{l}\text { neuralgia, neurasthenia, neuritis, nerve exhaustion, grippe } \\
\text { catalepsy, psychosis, prostration, inertia, anxiety, and paranoia }\end{array}$ \\
\hline $\begin{array}{l}\text { McCall S } \\
\text { et al, } 2008[8]\end{array}$ & 1918 & Spanish flu & Encephalitis Lethargica & $\begin{array}{l}\text { High fever, headache, double vision, delayed physical and mental } \\
\text { response, lethargy }\end{array}$ \\
\hline $\begin{array}{l}\text { Meals RW, } \\
1935 \text { [9] }\end{array}$ & 1935 & Diptheria & atypical poliomyelitis & $\begin{array}{l}\text { severe headache, painful oculomotion, and gastrointestinal } \\
\text { symptoms, and some patients presented with "mental dullness" and } \\
\text { a lack of ability to concentrate }\end{array}$ \\
\hline $\begin{array}{l}\text { Acheson ED. } \\
1959[10]\end{array}$ & 1956 & $\begin{array}{l}\text { Atypical } \\
\text { poliomyelitis }\end{array}$ & $\begin{array}{l}\text { myalgic } \\
\text { encephalomyelitis(ME) }\end{array}$ & headache, myalgia, paresis, and mental symptoms \\
\hline
\end{tabular}

Epidemiology of Chronic Fatigue Syndrome (CFS):

No uniform nomenclature has been established for this so-called long COVID. [11] The various terminologies that are being used include long-haul COVID-19 [12], post-COVID syndrome [13], chronic COVID syndrome [14], and more recently, post-acute sequelae of SARS-COV-2 infection (PASC). [15]

Although there is no fixed case definition or diagnostic criteria, however, three most commonly used diagnostic criteria include the 1994 CDC criteria [16], the 2006 Canadian Consensus Criteria [17], and the 2015 Institute of Medicine Criteria [18]. The required symptoms for all three criteria include persisting or relapsing chronic fatigue lasting for more than 6 months, with new and definite onset, causing a substantial reduction in daily activities, not alleviated by rest, and not due to ongoing exertion or any other medical condition.

Regarding the prevalence of long COVID, research is in progress, but according to studies around $75 \%$ to $87 \%$ of COVID infected patients experience at the minimum one of the symptoms at follow-up ranging from 7 to 12 weeks. [19-21] A recent systemic review found that dyspnea, fatigue and anosmia were the most frequently reported symptoms lasting more than 3 weeks.[22] The intensity of the acute phase of the illness does not appear to be linked to the development of long-term COVID symptoms. [21] Regarding recovery rates, the findings are highly variable between studies and full recovery between
$13 \%$ to $86 \%$ have been reported at followup ranging from 30 days to 186 days.[2325]

\section{Models of ME/CFS}

Chronic fatigue syndrome has been associated with several different pathogens, but the disease manifestation has been similar regardless of the causing pathogen [26] and the symptoms persist even in the absence of any notable abnormality in diagnostic testing. [27] This led to the 'hit and run' hypothesis, which proposes that following an infectious trigger, individuals experience disruption of immune, neurological and metabolic pathways. [28]

Even after multiple organ systems and signaling pathways investigation in both human and animal models, the mechanism of CFS remains poorly understood and is possibly multifactorial. Table 2 shows the possible mechanisms and their pathways.

Post-infectious stress triggers metabolic and endocrine abnormalities and studies have divulged that patients with chronic fatigue syndrome have metabolites like sphingolipids and phospholipids that bear a resemblance to a state of hibernation. [31]

The pathway of the virus also might involve disruption of lymphatic drainage from the microglia in the brain. One of the major pathways of the brain's lymphatic drainage is via the perivascular spaces along the olfactory nerves through the cribriform plate into the nasal mucosa. [32] The virus affecting this pathway can also explain the anosmia observed in some patients of COVID-19. This disturbance leads to an increase of pro-inflammatory agents, like 
post-infectious cytokines such as interferongamma, and interleukin 7 [33] which have been hypothesized to affect the neurological control of the 'Glymphatic System' as observed in CFS.

Table 2

\begin{tabular}{|l|l|}
\hline \multicolumn{1}{|c|}{ mechanism } & \multicolumn{1}{c|}{ Pathways } \\
\hline Immune/inflammatory [28] & $\begin{array}{l}\text { Chronic inflammation: } \begin{array}{c}\text { 1) abnormal cytokine signaling } \\
\text { 2) altered natural killer cell functions } \\
\text { 3) decreased function of Th1 cells }\end{array} \\
\text { Autoimmune phenomenon: 1) molecular mimicry } \\
\text { 2) autoreactive B cells } \\
\text { 3) anticholinergic receptor antibodies }\end{array}$ \\
\hline Central Nervous system involvement [29] & $\begin{array}{l}\text { 1) Demyelination of nerves } \\
\text { 2) Neuronal degeneration and necrosis } \\
\text { 3) Altered cerebral blood flow and connectivity }\end{array}$ \\
\hline Mitochondrial dysfunction [30] & $\begin{array}{l}\text { 1) Increased apoptosis } \\
\text { 2) Decreased energy production } \\
\text { 3) Increased reactive oxygen species. }\end{array}$ \\
\hline
\end{tabular}

The increase of cytokines in the Central Nervous System (CNS) may cause post-viral symptoms as pro-inflammatory cytokines pass through the blood-brain barrier to the hypothalamus, causing autonomic dysfunction which can lead to high fever and in the longer-term cause disruption of the sleep/wake cycle, cognitive dysfunction and persistent continuous lethargy. [34]

\section{Implications for Monitoring Long-Term Neuropsychiatric and Cognitive Sequelae}

Evidence from previous outbreaks of SARS-CoV-1 and MERS and current reports of neurological and neuropsychiatric complications following COVID-19, it can be assumed that a large number of survivors will experience numerous neuropsychiatric and cognitive symptoms, which are likely to have a profound effect on their mental, physical, and cognitive well-being, eventually affecting their emotional, occupational, and financial conditions. In some cases, full-scale development of neurological or psychiatric illness may occur. Some of these patients may experience mild cognitive problems and which can further increase their risk of developing dementia. As the effects of long COVID can be intense, monitoring of longterm neuropsychiatric and cognitive sequelae becomes crucial. $[35,36]$

\section{Management of neurological effects of COVID-19 and Chronic fatigue syndrome}

\begin{tabular}{|c|c|c|}
\hline Meningoencephalitis & $\begin{array}{l}\text { MRI-no specific findings, cortical hyper } \\
\text { densities } \\
\text { EEG-epileptic discharges } \\
\text { CSF- lymphocytic pleocytosis of }>100 \\
\text { cells/ } \mu \text { l }\end{array}$ & $\begin{array}{l}\text { High dose therapy with methylprednisolone, } \\
\text { Plasma exchange }\end{array}$ \\
\hline $\begin{array}{lr}\text { acute inflammatory } & \begin{array}{r}\text { demyelinating } \\
\text { polyneuritis-AIDP }\end{array} \\
\text { (Gundrome) } & \end{array}$ & $\begin{array}{l}\text { CSFfinding=cytoalbuminary dissociation, } \\
\text { increase in total protein, increased cell count }\end{array}$ & $\begin{array}{l}\text { Intravenous immunoglobulins, plasma } \\
\text { exchange. }\end{array}$ \\
\hline $\begin{array}{l}\text { Acute disseminated encephalomyelitis } \\
\text { (ADEM) }\end{array}$ & $\begin{array}{l}\text { MRI }=\text { large lesions in medullary canal and } \\
\text { basal ganglia } \\
\mathrm{CSF}=\text { pleocytosis }<100 \text { cells } / \mu \mathrm{l}\end{array}$ & High dose intravenous corticosteroids. \\
\hline Cerebrovascular diseases & CT or MRI & intravenous thrombolysis or thrombectomy \\
\hline Epileptic seizures & EEG & antiepileptic therapy \\
\hline $\begin{array}{l}\text { Disorders of the chemosensory system: } \\
\text { anosmia, ageusia }\end{array}$ & $\begin{array}{l}\text { UPSIT test for olfactory identification } \\
\mathrm{CT} / \mathrm{MRI}=\text { mucosal swelling with secretion in } \\
\text { the olfactory duct }\end{array}$ & $\begin{array}{l}\text { Complete or extensive improvement within } 2 \text { - } \\
3 \text { weeks. } \\
\text { If persists for a longer period, a therapy with } \\
\text { consistent, structured "olfactory training" can } \\
\text { be attempted. }\end{array}$ \\
\hline
\end{tabular}

The understanding of the management of long COVID can be split into two parts: a) management of the neurological effects which includes 
meningo-encephalitis, cerebrovascular disease b) management of prolonged fatigue, dyspnea and lethargy.

Regarding the neurological effects of COVID-19, no specific treatment guideline has been established. However, the German Society of Neurology published the first neurological manifestation guideline for the care of patients with a neurological disease with and without SARS-CoV-2 infection. [37]

\section{Management of Chronic Fatigue syndrome}

During the initial visits, the establishment of the patient's baseline after SARS-CoV-2 infection should be targeted. This process would require a thorough investigation of the patient's present and past medical, social, and family history, physical examination, and blood testing.

Consecutive visits must target a comprehensive understanding of the natural course of the disease and identify early new abnormalities. During the first 12 months of follow-up, additional evaluations can be carried out, like SARS-CoV-2 infectivity testing lung analyses, 6-minute walk tests, quality of life monitoring, fatigue, and general blood tests. [38]

According to the National Institute for Health and Care Excellence, graded exercise therapy and cognitive behavioral therapy might be beneficial for patients with CFS.[39] However, some recent studies have shown that graded exercise therapy might exacerbate post-exertional malaise in some patients.[40]

Additionally, patients with prolonged stay in the intensive care unit may also develop a post-intensive care syndrome with symptoms of anxiety, depression, or other neurological disorder, which demands a global evaluation and treatment of the after-effects caused due to prolonged bed rest and invasive mechanical ventilation. [41] Neuropsychological treatment can include psychotherapy, cognitive retraining, establishing routines, optimizing healthy lifestyles, Treatment for anxiety and depression will depend on the severity of the symptoms and their impact on the patient's current social and occupational functioning. Medication management may be necessary. Selective serotonin reuptake inhibitors (SSRIs) are the first line of treatment for symptoms of depression and anxiety. [42]

Rehabilitation of patients after COVID-19 infection is as important as medical assistance. For rehabilitation, a multidisciplinary approach should be taken that meets the specific needs of the individual. Two fundamental features of the rehabilitation program include respiratory function [43] and physical re-education of peripheral muscle function and increase of exercise capacity. Some of the rehabilitation techniques include proper posturing, physical exercise, aerobic training, and other techniques which improve strength, static and dynamic balance. The aim of the overall management procedure should be to improve the quality of life of the patient and reintegrating the individual into society. [44]

Other than stress following infection, strain due to factors like the death of loved ones, loss of job, months of forced quarantine, lack of supply, stigma makes an individual more vulnerable to mental illness, which demands prompt and active participation of mental health care workers.[45]

The approach for management of CFS should be based on conservative symptom relief strategies, referral to specialists for co-management of comorbidities, and a multidisciplinary approach to social, cultural, and financial support. However, further research will be required to determine the benefit of any specific treatment for this condition.

\section{CONCLUSION}

The neuropsychiatric and cognitive complications following COVID-19 infection are diverse and affect a large proportion of COVID-19 survivors. A surge in neuropsychiatric manifestations like 
depression, anxiety, PTSD, and in certain cases severe mental illnesses is noticed. Cognitive sequelae are also likely to be diverse and a comprehensive cognitive assessment must be considered for such patients. Regular monitoring for the emergence of new symptoms is highly crucial for planning adequate health care delivery, early intervention, and allocation of resources adequately. Early intervention for emerging cognitive problems will be critical for improving the quality of life and early reintegration into society for many COVID-19 survivors

\section{Acknowledgement: None}

\section{Conflict of Interest: None}

\section{REFERENCES}

1. Jin YH, Cai L, Cheng ZS, Cheng H, Deng T, Fan YP, et al. A rapid advice guideline for the diagnosis and treatment of 2019 novel coronavirus (2019-nCoV) infected pneumonia (standard version). Mil Med Res 2020; 7:1-23.

2. Johns Hopkins University \& Medicine. COVID-19 Dashboard by the Center for Systems Science and Engineering (CSSE) at Johns Hopkins University (JHU) [Internet]. 2020. Available from: https://coronavirus.jhu.edu/map.html.

3. Rubin R. As Their Numbers Grow, COVID19 "Long Haulers" Stump Experts. JAMA. 2020;324(14):1381.

4. Woo M, Malsy J, Pöttgen J, Seddiq Zai S, Ufer F, Hadjilaou A et al. Frequent neurocognitive deficits after recovery from mild COVID-19. Brain Communications. 2020;2(2).

5. National Institute for Health and Care Excellence. COVID-19 Rapid Guideline: Managing the Long-Term Effects of COVID-19. London, UK: National Institute for Health and Care Excellence; 2020

6. Lim EJ, Son CG. Review of case definitions for myalgic encephalomyelitis / chronic fatigue syndrome (ME / CFS). J Transl Med. 2020;18:1-10.

7. Honigsbaum M, Krishnan L. Taking pandemic sequelae seriously: From the Russian influenza to COVID-19 longhaulers. Lancet. 2020;396(10260):1389-91
8. McCall S, Vilensky JA, Gilman S, Taubenberger JK. The relationship between encephalitis lethargica and influenza: A critical analysis. J Neurovirol. 2008;14 (3): $177-85$

9. Meals RW, Hauser VF, Bower AG. Poliomyelitis-the Los Angeles epidemic of 1934: Part I. Cal West Med. 1935;43(2):123-25

10. Acheson ED. The clinical syndrome variously called benign myalgic encephalomyelitis, Iceland disease and epidemic neuromyasthenia. Am J Med. 1959;26(4): 569-95

11. Nabavi, N. Long covid: How to define it and how to manage it. BMJ 2020, 370, m3489

12. Aucott, J.N.; Rebman, A.W. Long-haul COVID: Heed the lessons from other infection-triggered illnesses. Lancet 2021, 397, 967-968

13. Garg, P.; Arora, U.; Kumar, A.; Wig, N. The "post-COVID" syndrome: How deep is the damage? J. Med. Virol. 2021, 93, 673674

14. Baig, A.M. Deleterious Outcomes in LongHauler COVID-19: The Effects of SARSCoV-2 on the CNS in Chronic COVID Syndrome. ACS Chem. Neurosci. 2020, 11, 4017-4020.

15. Kalter, L.; WebMD Health News. Fauci Introduces New Acronym for Long COVID (Retrieved 17 March 2021). Available online:

ttps://www.medscape.com/viewarticle/9464 19

16. Fukuda K, Straus SE, Hickie I, et al. The chronic fatigue syndrome: a comprehensive approach to its definition and study. 1994; 121:953-959.

17. Carruthers BM, Jain AK, De Meirleir KL, et al. Myalgic encephalomyelitis/chronic fatigue syndrome: a clinical case definition and guidelines for medical practitioners (an overview of the Canadian consensus document). J ChronicFatigue Syndr 2003; 11: 7-115.

18. Clayton EW. Beyond myalgic encephalomyelitis/chronic fatigue syndrome: an IOM report on redefining an illness. JAMA 2015; 313:1101-1102.

19. Carfî, A.; Bernabei, R.; Landi, F.; Gemelli Against COVID-19 Post-Acute Care Study Group. Persistent Symptoms in Patients 
After Acute COVID-19. JAMA 2020, 324, 603-605. [CrossRef]

20. Arnold DT, Hamilton FW, Milne A, et al. Patient outcomes after hospitalisation with COVID-19 and implications for follow-up: results from a prospective UK cohort. Thorax. Epub ahead of print 3 December 2020. DOI: 10.1136/ thoraxjnl-2020216086.

21. Mandal S, Barnett J, Brill SE, et al. 'LongCOVID': a cross-sectional study of persisting symptoms, biomarker and imaging abnormalities following hospitalisation for COVID-19. Thorax. Epub ahead of print 10 November 2020. DOI:10.1136/thoraxjnl-2020-215818.

22. Ayoubkhani D, Khunti K, Nafilyan V, et al. Epidemiology of post-COVID syndrome following hospitalisation with coronavirus: a retrospective cohort study. Epidemiology. Epub ahead of print 15 January 2021. DOI:10.1101/2021.01.15.21249885.85.

Pellaud C, Grandmaison G, Pham

23. Huang C, Huang L, Wang Y, et al. 6-month consequences of COVID-19 in patients discharged from hospital: a cohort study. Lancet.Epub ahead of print 8 January 2020. DOI:10.1016/S0140-6736(20)32656-8.

24. Halpin SJ, McIvor C, Whyatt G, et al. Postdischarge symptoms and rehabilitation needs in survivors of COVID-19 infection: a crosssectional evaluation. J Med Virol. Epub ahead of print 30 July 2020. DOI: 10.1002/jmv.26368.

25. Zhao Y-M, Shang Y-M, Song W-B, et al. Follow-up study of the pulmonary function and related physiological characteristics of COVID-19 survivors three months after recovery. E Clinical Medicine 2020; 25: 100463.

26. Hickie I, Davenport T, Wakefield D, et al. Post-infective and chronic fatigue syndromes precipitated by viral and nonviral pathogens: prospective cohort study. BMJ 2006; 333: 575.

27. Prins JB, van der Meer JW and Bleijenberg G. Chronic fatigue syndrome. Lancet 2006; 367: 346-355.

28. Rasa S, Nora-Krukle Z, Henning N, et al. Chronic viral infections in Myalgic Encephalomyelitis/Chronic Fatigue Syndrome (ME/CFS). J Transl Med 2018; 16: 268.

29. Maksoud R, du Preez S, Eaton-Fitch N, et al. A systematic review of neurological impairments in myalgic encephalomyelitis/chronic fatigue syndrome using neuroimaging techniques. PLoS One 2020; 15: e0232475.

30. Filler K, Lyon D, Bennett J, et al. Association of mitochondrial dysfunction and fatigue: a review of the literature. $B B A$ Clin 2014; 1: 12-23.

31. Hives L, Bradley A, Richards J, et al. Can physical assessment techniques aid diagnosis in people with chronic fatigue syndrome/myalgic encephalomyelitis? A diagnostic accuracy study. BMJ Open 2017;7:e017521.

32. Kida S, Pantazis A, Weller RO. CSF drains directly from the subarachnoid space into nasal lymphatics in the rat. Anatomy, histology and immunological significance. Neuropathol Appl Neurobiol 1993;19:4808. Montoya JG.

33. Holmes TH, Anderson JN, et al. Cytokine signature associated with disease severity in chronic fatigue syndrome patients. Proc Natl Acad Sci 2017;114:E7150-8

34. Hives L, Bradley A, Richards J, et al. Can physical assessment techniques aid diagnosis in people with chronic fatigue syndrome/myalgic encephalomyelitis? A diagnostic accuracy study. BMJ Open 2017;7:e017521

35. Hampshire, A., Trender, W., Chamberlain, S., Jolly, A., Grant, J. E., Patrick, F., et al. (2020). Cognitive deficits in people who have recovered from COVID-19 relative to controls: an $\mathrm{N}=84,285$ online study. medRxiv [Preprint]. doi: 10.1101/ 2020.10.20.20215863

36. Woo, M. S., Malsy, J., Pöttgen, J., Seddiq Zai, S., Ufer, F., Hadjilaou, A., et al. (2020). Frequent neurocognitive deficits after recovery from mild COVID-19. Brain Commun. 2:fcaa205. doi: 10.1093/ braincomms/fcaa205

37. Berlit, P.; Bösel, J.; Gahn, G.; Isenmann, S.; Meuth, S.G.; Nolte, C.H.; Pawlitzki, M.; Rosenow, F.; Schoser, B.; Thomalla, G.;et al. Neurological manifestations of COVID19 "-guideline of the German society of neurology. Neurol. Res. Pract. 2020, 2, 51.

38. Portolés, J.; Marques, M.; López-Sánchez, P.; de Valdenebro, M.; Muñez, E.; Serrano, M.L.; Malo, R.; García, E.; Cuervas, V.Chronic kidney disease and acute kidney injury in the COVID-19 Spanish outbreak. 
Nephrol. Dial. Transplant. 2020, 35, 13531361.

39. Lv D, Chen X, Mao L, et al. Pulmonary function of patients with 2019 novel coronavirus induced pneumonia: a retrospective cohort study. Research Square. April 2020. DOI:10.21203/rs.3.rs24303/v1.

40. Larun L, Brurberg KG, Odgaard-Jensen J, et al. Exercise therapy for chronic fatigue syndrome. Cochrane Database Syst Rev 2019; 10:CD003200.

41. Sheehy, L.M. Considerations for Postacute Rehabilitation for Survivors of COVID-19. JMIR Public Health Surveill. 2020, 6, 19462

42. https://www.mohfw.gov.in/pdf/Guidelinesfo rDeliveryofMentalMentalHealthcareService sduringtheCOVID19

43. Liu, K.; Zhang,W.; Yang, Y.; Zhang, J.; Li, Y.; Chen, Y. Respiratory rehabilitation in elderly patients with COVID-19: A randomized controlled study. Complement. Ther. Clin. Pract. 2020, 39, 101166

44. Carda, S.; Invernizzi, M.; Bavikatte, G.; Bensmaïl, D.; Bianchi, F.; Deltombe, T.; Draulans, N.; Esquenazi, A.; Francisco, G.E.; Gross, R.; et al. COVID-19 pandemic. What should Physical and Rehabilitation Medicine specialists do? A clinician's perspective. Eur. J.Phys. Rehabil. Med. 2020, 56, 515-524

45. Mak I.W.C., Chu C.M., Pan P.C., Yiu M.G.C., Chan V.L. Long-term psychiatric morbidities among SARS survivors. Gen. Hosp. Psychiatry. 2009;31(August (4)): 318-326.

How to cite this article: Ray A, Saini N, Parkash $\mathrm{R}$ et.al. Post-COVID chronic fatigue syndrome: new challenge ahead. International Journal of Science \& Healthcare Research. 2021; 6(3): 472-478. DOI: https://doi.org/10.52403/ijshr. 20210776 